\title{
Effect of light entrainment and temperature on the reproductive cycle in the male hedgehog (Erinaceus europaeus)
}

\author{
M. Saboureau and B. El Omari* \\ Centre d'Etudes Biologiques de Chizé, CNRS, F-79360 Villiers-en-Bois, France
}

\begin{abstract}
The role of photoperiod in the entrainment and synchronization of the reproductive cycle of male hedgehogs, seasonal breeders and hibernating mammals, was investigated. Groups of adult hedgehogs were either maintained outdoors (controls, $n=6$ ) or submitted to accelerated 6-month artificial light regimens under constant ambient temperatures $\left(20 \pm 2^{\circ} \mathrm{C}\right.$ versus $5 \pm 1^{\circ} \mathrm{C}$ ) in light-proofed rooms. The daily duration of light was varied sinusoidally to produce an amplitude change from $8 \mathrm{~h}$ (winter solstice) to $16 \mathrm{~h}$ (summer solstice) during the 6 -month light cycle. Animals were transferred from outdoors to a high ambient temperature $\left(20 \pm 2^{\circ} \mathrm{C}\right)$ and submitted to accelerated 6-month light regimens at two times of the year: from winter solstice (Group I, $n=14$ ) with increasing daylengths (from 8 to $16 \mathrm{~h}$ ) and from summer solstice (Group 2, $n=8$ ) with decreasing daylengths (from 16 to $8 \mathrm{~h}$ ). The light regimens were then reversed for Groups 1 and 2. After the first 6-month cycle, the animals in Group 1 were allocated to two groups and maintained under the same initial light regimen but submitted to two ambient temperatures: Group I $(n=7)$ was maintained at $20 \pm 2{ }^{\circ} \mathrm{C}$ and Group $3(n=7)$ was transferred to a cold environment $\left(5 \pm 1^{\circ} \mathrm{C}\right)$. In control and experimental animals, testicular volume was estimated and blood samples were obtained twice a month to measure plasma testosterone and LH concentrations by radioimmunoassay. In all groups, all the parameters of the reproductive activity studied (testicular volume, testosterone and LH concentrations) were entrained and synchronized by the 6-month light rhythm and two cycles were observed in a year. Reproductive activity was maximum during the long days (light $>12 \mathrm{~h}$ ) and minimum during the short days (light $<12 \mathrm{~h}$ ). In the experimental animals and in the controls, the amplitude of variations in the parameters studied were similar. The recrudescence of reproductive activity took place just before the artificial spring equinox (short and increasing daylengths), whereas regression always occurred near the autumn equinox ( $12 \mathrm{~h}$ light: $12 \mathrm{~h}$ dark), as in the controls kept in a natural environment. The regular incidence of involution at the autumn equinox indicates that there is a period of photosensitivity to decreasing daylengths in summer. In the experimental animals, the resting season was usually 2 months. A comparison of Groups 1 and 2 that had undergone reversed light regimens also showed that the reproductive parameters were driven in opposition. In Groups 1 and 3, no significant effect of ambient temperature (high or low) on the entrainment of the reproductive cycle by the photoperiodic rhythm was observed. These results clearly indicate that photoperiod is of prime importance among the environmental factors controlling reproduction in hedgehogs and can entrain and synchronize the seasonal changes of the reproductive cycle.
\end{abstract}

\section{Introduction}

In natural conditions, mammals from temperate and arctic regions regulate and adjust their reproductive cycle to a period of one year according to external factors. Among these external factors, seasonal changes in daylength are constant from year to year, unlike other environmental factors such as temperature, rainfall and food availability. Daylength is, therefore, a good predictor of the time of the year, which it is necessary to

*Present address: Ecole Nationale d'Agriculture de Meknes, B.P.S./40, MEKNES, Maroc.

Received 31 December 1992. anticipate for the timing of breeding (Turek and Campbell, 1979; Lincoln and Short, 1980; Ortavant et al., 1985). The role of photoperiod in the regulation of reproduction was first established on animals subjected to transequatorial displacement (Marshall, 1937; Thwaites, 1965), or submitted to reversed annual photoperiodic schedules (Wodzicka-Tomaszewska et al., 1967; Pelletier and Ortavant, 1970; Karsch et al., 1984). More recently accelerated photoperiodic rhythms have been used, with different patterns of light changes, including sine variations (Rougeot, 1969; Lindsay et al., 1984; Pelletier et al., 1986; Pohl, 1987), alternating periods of long and short days (Lincoln and Peet, 1977; Lincoln, 1978) and more complex designs, with 
light provided in two daily photofractions (Pelletier and Thimonier, 1987).

In hedgehogs, which are seasonal breeders, the cycle of reproduction in the natural environment is characterized by a resting period in autumn and a period of maximum activity from February-March to August-September (Saboureau and Boissin, 1978; Saboureau and Dutourné, 1981). In adult male hedgehogs, the seasonal variations in gonadal and pituitary activities are parallel during the year (Fowler, 1988; El Omari et al., 1989). The reactivation of reproduction occurs from the beginning of winter (low and increasing daylengths) in spite of low temperatures, and the involution is regular at the end of summer when daylengths are decreasing and temperatures are still high (Saboureau and Boissin, 1983). In hibernating mammals, the regular alternation of reproduction and hibernation is often related to endogenous rhythms (Boissin and Canguilhem, 1988), as exemplified by the entry in hibernation at the beginning of autumn and the spontaneous reactivation of reproduction before the end of hibernation. There have been numerous studies on the effect of temperature in this species, but research on the effect of light has been limited to some data relative to the temporal relationships of the daily and seasonal locomotor activity rhythms (Saboureau et al., 1979), and to an attempt to explain the regulation of gonadal activity (Saboureau, 1981). Consequently, the exact role of photoperiod on the entrainment and synchronization of the reproductive cycle has not yet been established.

The present study was therefore undertaken to determine whether the reproductive cycle in male hedgehogs was effectively synchronized and driven by photoperiodic changes. For this purpose, changes in the testes (volume and plasma testosterone concentrations), and in gonadotrophin concentrations (plasma LH concentrations) were studied in animals submitted to artificial light regimens lasting 6 months and uniform temperature conditions. These were compared with control animals kept under natural climatic conditions.

\section{Materials and Methods}

\section{Animals}

Male hedgehogs (Erinaceus europaeus) used in this study were born in the Centre d'Etudes Biologiques de Chizé in midwestern France $\left(46^{\circ} 07^{\prime} \mathrm{N}, 0^{\circ} 25^{\prime} \mathrm{W}\right)$. The animals were housed individually and kept under natural climatic conditions of light, temperature and rainfall until adulthood, at the beginning of the experiments. They were fed daily with a mixture of crushed chicken meat and dog biscuits (Canina: Duquesne-Purina, St-Quentin); water was always available.

\section{Experimental design}

Animals were allocated randomly to control, or treatment groups. Six animals (controls) were kept outdoors under natural variations of daylight and environmental temperature during the whole time of the experiments. Groups of experimental animals, kept in light-proof rooms, were submitted, at two times of the year (from winter and summer solstices) to an accelerated (six months) artificial light regimen and uniform ambient temperature conditions. The rooms were illuminated by fluorescent tubes simulating the full visible and ultraviolet spectrum of natural white light. The light intensity was about 100 lux at the level of the animal; the regimen was varied to fit a sine curve and was manually adjusted every two days. The amplitude of daylength varied from a minimum of $8 \mathrm{~h}$ to a maximum of $16 \mathrm{~h}$; the onset and end of lighting was controlled by an electronic clock.

On the day of the winter solstice, 14 animals were transferred from outdoors ( $8 \mathrm{~h} \mathrm{light)}$ to the 6-month artificial light regimen with daylength increasing from 8 to $16 \mathrm{~h}$ over the six month period; the ambient temperature was maintained high and constant $\left(20 \pm 2{ }^{\circ} \mathrm{C}\right)$ during the 18 months of the experiment (Group 1).

On the day of the summer solstice, eight animals were transferred from outdoors ( $16 \mathrm{~h}$ light) to a similar 6-month artificial light regimen with daylength decreasing from 16 to $8 \mathrm{~h}$ over the six month period; the ambient temperature was maintained at $20 \pm 2{ }^{\circ} \mathrm{C}$ during the 12 months of the experiment (Group 2).

Groups 1 and 2, therefore, both had 6-month light regimens, but in opposite phases.

After the first 6-month cycle the animals in Group 1 were allocated to two groups and maintained under the same initial light regimen but submitted to two ambient temperatures: Group $1(n=7)$ was maintained at $20 \pm 2^{\circ} \mathrm{C}$ and Group 3 $(n=7)$ was transferred to a cold environment $\left(5 \pm 1^{\circ} \mathrm{C}\right)$.

\section{Collection of blood samples}

Every two weeks, at the same time in the morning (3-5 h after dawn), a single blood sample was taken, from control and experimental animals, by intracardiac puncture under light halothane anaesthesia (Fluothan: Pitman-Moore France S. A., Meaux). Blood samples were placed into heparinized tubes and were kept on ice until centrifugation $(3900 \mathrm{~g}, 10 \mathrm{~min})$. Plasma was divided into several aliquots and stored at $-25^{\circ} \mathrm{C}$ until used in assays.

At the same time, the body mass of the animals was recorded and the testicular volume was estimated by palpation according to an arbitrary unit scale (from $I$ to 5 a.u.); this index correlated with measured data (Saboureau, 1981). Testes are in an intraabdominal position in hedgehogs and this procedure avoids injury resulting from laparotomy.

\section{Hormone assays}

Testosterone assay. Plasma testosterone concentrations were measured by a radioimmunoassay method without chromatography (Saboureau and Dutourné, 1981). Intra- and interassay coefficients of variation were 4 and $10 \%$, respectively, and the sensitivity was $<10 \mathrm{pg}$ per tube.

LH assay. Plasma LH was determined by a double-antibody heterologous radioimmunoassay as described by El Omari $e t$ al. (1989). Purified rabbit LH (RbLH, AFP-559; NIAMDD, NIH: Bethesda, MD) was used as standard and, also, for radioiodination. An anti-rat LH serum (used at a final dilution of 1 : 65000 ) and an anti-rabbit $\gamma$-globulin serum raised from sheep (INRA, Nouzilly) were used as first and precipitating second antibodies, respectively. The sensitivity of the method, determined as the minimal detectable standard dose, was less than $7.9 \mathrm{pg}$ per assay tube, i.e., less than $0.20 \mathrm{ng} \mathrm{ml}^{-1}$ plasma. Serial Downloaded from Bioscientifica.com at 04/26/2023 11:24:04AM 

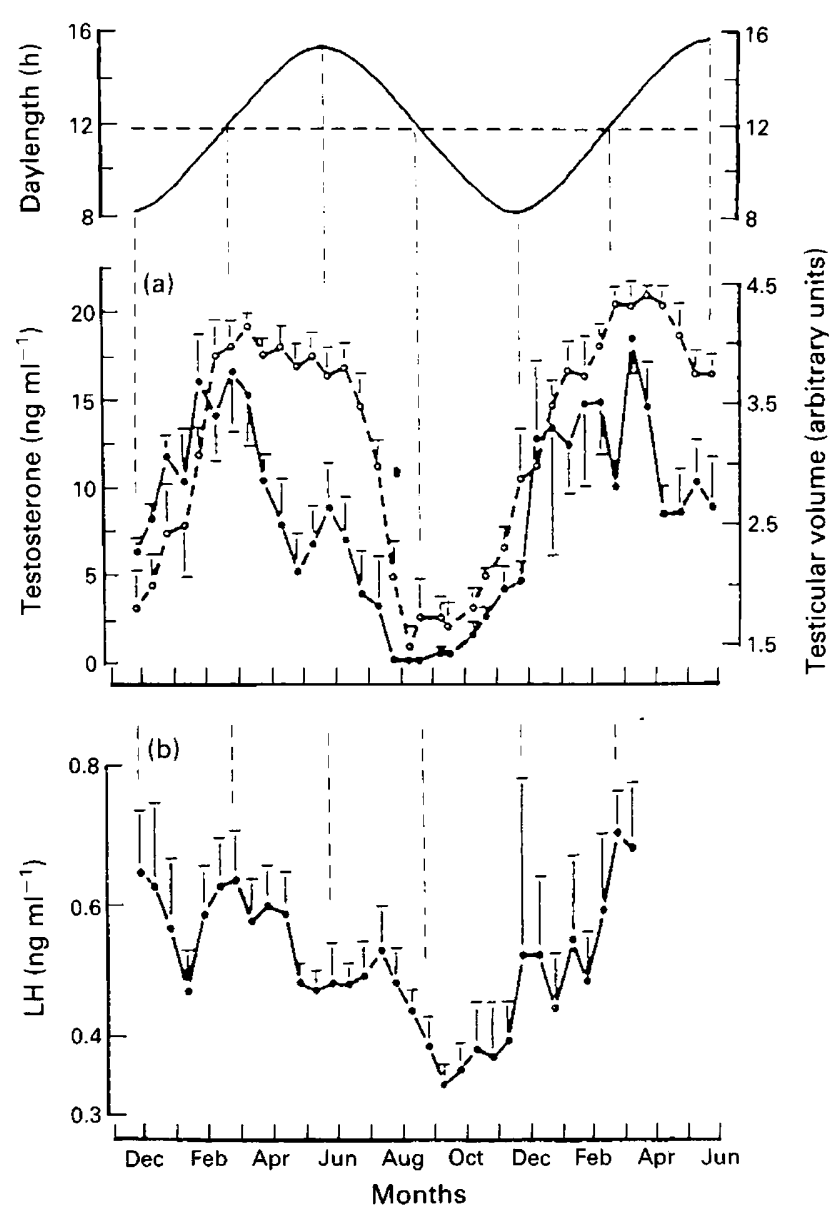

Fig. 1. Seasonal changes in daylength (top of figure), (a) testicular volume (c) and plasma testosterone ( $\bullet$ ), and (b) LH concentrations in male hedgehogs maintained outdoors. The animals $(n=6)$ were sampled twice a month, during 1.5 years, from the winter solstice. Data are means \pm SEM.

dilutions of hedgehog plasma were parallel to the standard curve. Intra- and interassay coefficients of variation were $4.7 \%$ and $7.9 \%$, respectively.

\section{Statistical analysis}

All the data were presented as means \pm SEM. Analysis of variance was used for statistical comparisons of the mean values at different times in the same group, and between different experimental groups.

\section{Results}

\section{Control group}

In control animals, maintained under natural variations of daylength and ambient temperature, the reproductive parameters (testicular volume, testosterone and LH concentrations) showed a clear seasonal pattern (Fig. 1). Maximum reproductive activity was observed from mid-winter to mid-summer; testicular volume was maximum and constant ( $>3.5$ a.u.) and testosterone and LH concentrations increased in two main phases. The first phase occurred from January-February to April, with the highest plasma concentrations (testosterone $14-17 \mathrm{ng} \mathrm{ml}^{-1} ; \mathrm{LH}$ $>0.6 \mathrm{ng} \mathrm{ml}^{-1}$ ) and the second from June to August with lower, intermediate concentrations (testosterone $5-9 \mathrm{ng} \mathrm{ml}^{-1}$; $\mathrm{LH}$ $>0.5 \mathrm{ng} \mathrm{m}^{-1}$ ). Reproductive regression occurred from midAugust to mid-September, during long but decreasing daylengths (13.5-12 h), in spite of high ambient temperatures. In autumn, during the resting season, all the parameters were minimum (testicular volume $<1.5 \mathrm{a} . \mathrm{u}_{\text {.; }}$ testosterone $0.2-1.5 \mathrm{ng}$ $\mathrm{ml}^{-1}$; $\mathrm{LH} 0.3-0.4 \mathrm{ng} \mathrm{ml}^{-1}$ ). Recrudescence of reproductive activity began spontaneously in December-January, while the animals were still hibernating, and even though daylengths were at their shortest $(8-9 \mathrm{~h})$ and ambient temperatures at their lowest for the year.

\section{Effect of a 6-month artificial light regimen beginning in December} (winter solstice) with daylength increasing (from $8 \mathrm{~h}$ to $16 \mathrm{~h}$ ) (Group 1)

From the winter solstice, male hedgehogs with low testicular activity (testicular volume $<2.0$ a.u.; testosterone $5.96 \pm$ $0.84 \mathrm{ng} \mathrm{ml}^{-1}$ ) but already high $\mathrm{LH}$ concentrations $(0.51 \pm$ $0.07 \mathrm{ng} \mathrm{ml}^{-1}$ ) were transferred from their natural environment to the artificial 6-month light regimen and maintained at a constant high ambient temperature $\left(20 \pm 2^{\circ} \mathrm{C}\right)$. Under these conditions, all the parameters of reproductive activity (Fig. 2) correlated highly and positively with the duration of the light phase, as they were entrained and synchronized by the 6-month light rhythm. During the 18 months of the study, three reproductive cycles were observed. Testicular volume and plasma concentrations of testosterone and $\mathrm{LH}$ were at a maximum during long days (light $>12 \mathrm{~h}$ ), at a minimum during short days (light $<12 \mathrm{~h}$ ), and showed the same amplitude of variation as in the controls. During the period of maximum activity, the patterns of testosterone and $\mathrm{LH}$ were characterized by a high peak (testosterone $\simeq 20 \mathrm{ng} \mathrm{ml}^{-1}$ on days 30,240 and $435 ; \mathrm{LH}$ $\simeq 0.6-0.7 \mathrm{ng} \mathrm{ml}^{-1}$ on days 75,255 and 435 ) during the increasing long days (light from $12 \mathrm{~h}$ to $16 \mathrm{~h}$ ) and a significant decrease $(P<0.05)$ to a lower plateau value (testosterone $10-15 \mathrm{ng}$ $\mathrm{ml}^{-1} ; \mathrm{LH} \simeq 0.4 \mathrm{ng} \mathrm{ml}^{-1}$ ) after the artificial summer solstice (light from $16 \mathrm{~h}$ to $12 \mathrm{~h}$ ). The recrudescence of reproductive activity took place as the short days increased in length (light from $10 \mathrm{~h}$ to $12 \mathrm{~h}$ ), just before the spring equinox for testosterone and $\mathrm{LH}$, and 15 days before for testicular volume. Regression was also rapid and significant for testosterone $(P<0.01)$ and LH $(P<0.05)$ after the autumn equinox (light from $12 \mathrm{~h}$ to $10 \mathrm{~h}$ ) with the decrease in testicular volume occurring 15 days later. The resting period, with the lowest concentrations of testosterone $\left(0.2-0.6 \mathrm{ng} \mathrm{ml}^{-1}\right)$ and $\mathrm{LH}(<0.3 \mathrm{ng}$ $\mathrm{ml}^{-1}$ ), had a duration of about two months. As in control animals, involution always occurred after the autumnal equinox (light $<12 \mathrm{~h}$ ).

Effect of a 6-month artificial light regimen beginning in June (summer solstice) with daylength decreasing from 16 to $8 \mathrm{~h}$ (Group 2)

At the beginning of the second light regimen, which occurred during the second part of the reproductive season, testicular Downloaded from Bioscientifica.com at 04/26/2023 11:24:04AM 

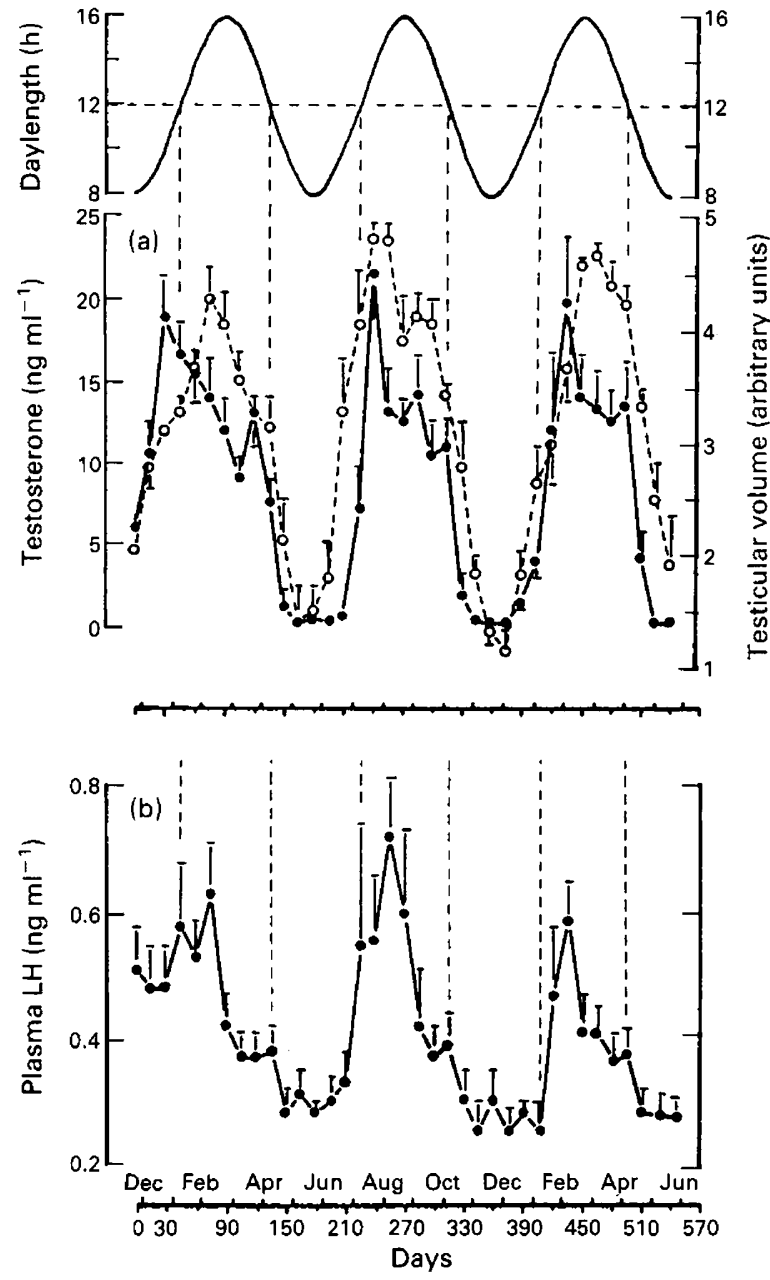

Fig. 2. Effects of a 6-month artificial light regimen (top of figure) beginning in December (winter solstice) with increasing daylengths and a high constant ambient temperature $\left(20 \pm 2^{\circ} \mathrm{C}\right)$ on (a) the testicular volume (o) and plasma testosterone concentrations ( $\bullet$ ) and (b) LH concentrations in male hedgehogs $(n=14$ from days $0-180$ and $n=7$ afterwards). Data are means \pm SEM.

volume ( $>3.5$ a.u.) and concentrations of testosterone $(6.01 \pm$ $\left.1.60 \mathrm{ng} \mathrm{ml}^{-1}\right)$ and $\mathrm{LH}\left(0.66 \pm 0.09 \mathrm{ng} \mathrm{ml}^{-1}\right)$ were still high. In spite of the high ambient temperature $\left(20 \pm 2^{\circ} \mathrm{C}\right)$, the accelerated decrease of daylength resulted in a rapid regression of reproductive parameters, and at the artificial autumn equinox (i.e. 1.5 months after the beginning of the experiment; $12 \mathrm{~h}$ light: $12 \mathrm{~h}$ dark) testosterone and $\mathrm{LH}$ concentrations were at a minimum. Reproductive activity was then entrained to a 6month cycle as in the former experiment with similar temporal characteristics (i.e. gonadal activity was at a maximum during long days and at a minimum during short days; recrudescence started before the spring equinox and regression occurred after the autumn equinox).

The photoperiod regimens were reversed for Groups 1 and 2. If the data from these two groups are superimposed, the different parameters of the reproductive cycle move into opposition, as illustrated by the profiles of testosterone concentrations (Fig. 4).
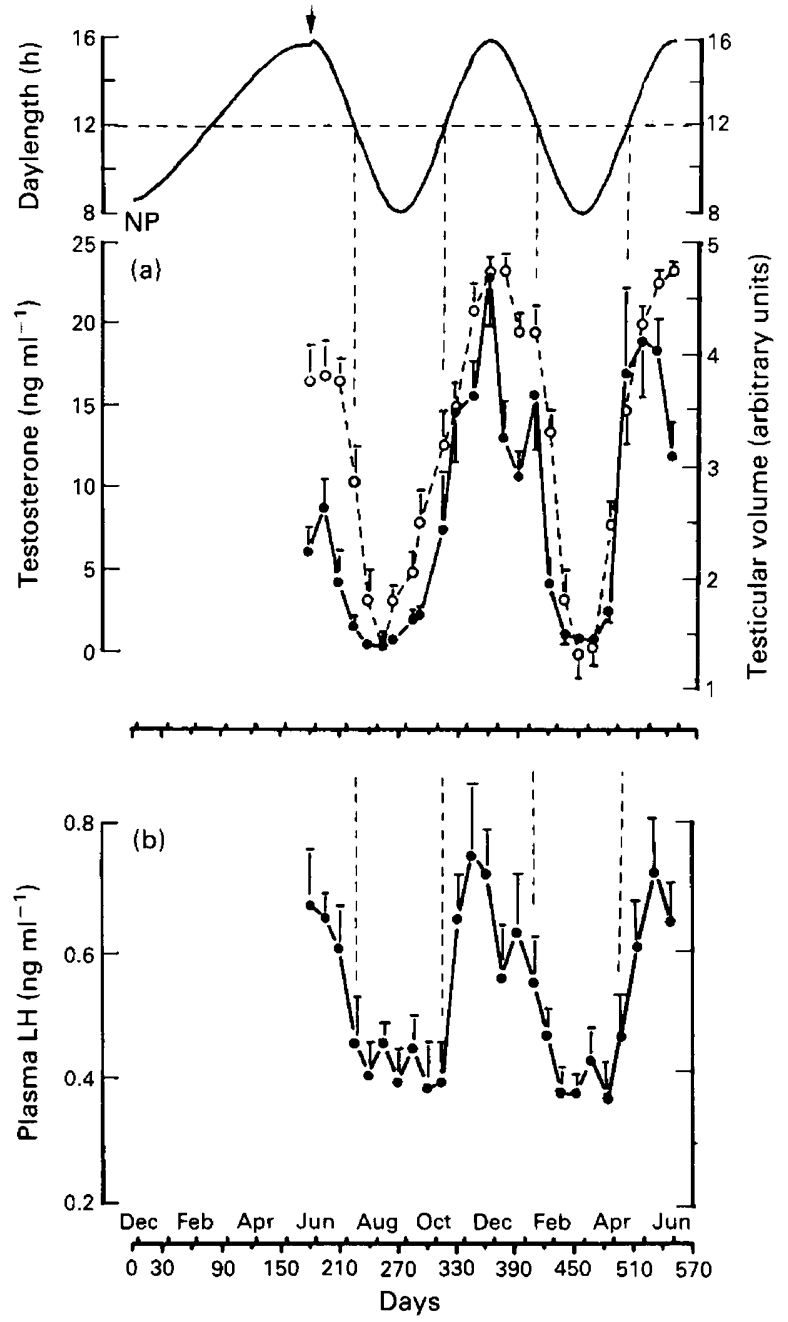

Fig. 3. Effects of a 6-month artificial light regimen (top of figure) beginning in June ( $\downarrow=$ summer solstice) with decreasing daylengths and under a high constant ambient temperature $\left(20 \pm 2{ }^{\circ} \mathrm{C}\right)$ on (a) the testicular volume $(0)$ and plasma testosterone concentrations $(\bullet)$ and (b) LH concentrations in hedgehogs $(n=8)$. Data are means \pm SEM. NP: natural photoperiod.

Effect of two ambient temperatures (high: $20 \pm 2^{\circ} \mathrm{C}$ versus low: $5 \pm 1^{\circ} \mathrm{C}$ ) with the same 6-month artificial light regimen (Group 3)

In Group 3, the effect of a low ambient temperature $\left(5 \pm 1^{\circ} \mathrm{C}\right)$ with the same initial light regimen was studied after the animals had been exposed to a first 6-month cycle at high ambient temperature $\left(20 \pm 2{ }^{\circ} \mathrm{C}\right)$. At $5^{\circ} \mathrm{C}$, testicular volume and testosterone and LH patterns were also entrained to the 6month light rhythm (Fig. 5) as in the other experiments. Nevertheless, $\mathrm{LH}$ concentrations stayed significantly higher at $5^{\circ} \mathrm{C}$ than at $20^{\circ} \mathrm{C}\left(<0.4 \mathrm{ng} \mathrm{ml}^{-1}\left(20^{\circ} \mathrm{C}\right.\right.$, days $\left.105-135\right)$ versus $>0.6 \mathrm{ng} \mathrm{ml} \mathrm{m}^{-1}\left(5^{\circ} \mathrm{C}\right.$, days $300-315$ and days $\left.450-465\right)$ : $P<0.01$ ) during the second part of the period of reproduction (decreasing long days). Irrespective of ambient temperatures, the involution of reproductive activity always occurred soon after the autumn equinox.

The superimposition of data from Groups 1 and 3 , as illustrated by the profiles of testosterone concentrations (Fig. 6), 

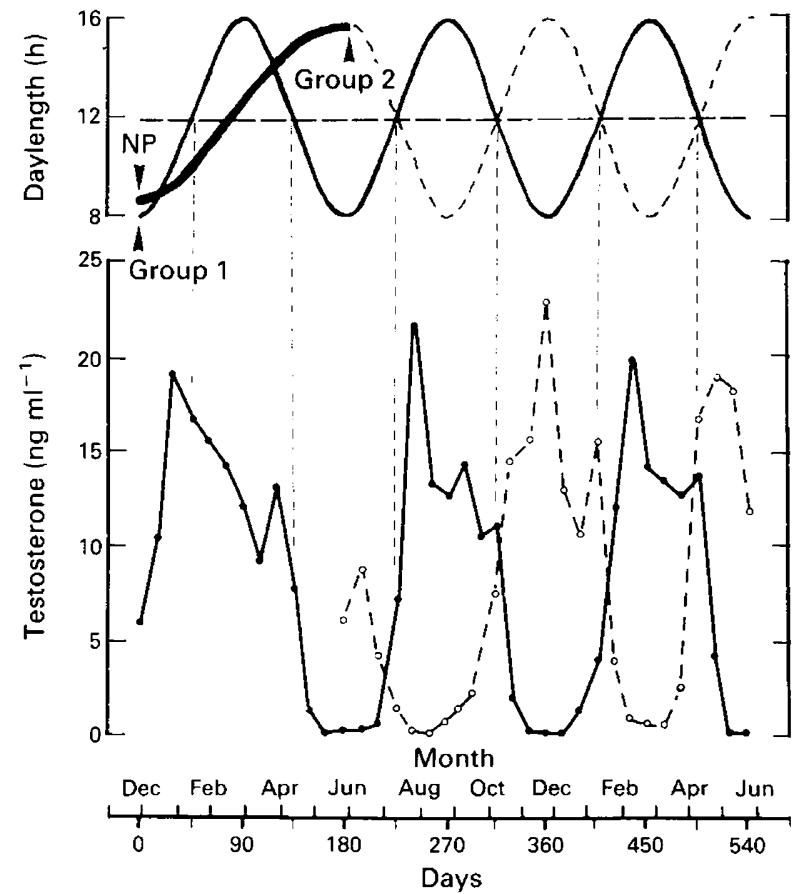

Fig. 4. Comparison of mean concentrations of plasma testosterone in male hedgehogs submitted to 6-month artificial light regimens at a high constant ambient temperature $\left(20 \pm 2^{\circ} \mathrm{C}\right) .(-\rightarrow)$ Group I: light regimen started at the beginning of winter solstice; (-० $\longrightarrow$ ) Group 2: light regimen started at beginning of summer solstice. NP: natural photoperiod.

confirmed that the effect of different ambient temperatures is of little importance in the entrainment of gonadal activity in male hedgehogs, compared with the effect of the photoperiodic regimen. However, a comparison of the patterns of testosterone of Groups $\mathrm{I}$ and 3 indicated that at $5^{\circ} \mathrm{C}$, there had been a 15 day advance in (a) the regression phase (end of the first cycle) at the autumn equinox (on day 315 the testosterone concentration for Group 1 was $11.08 \pm 1.75 \mathrm{ng} \mathrm{ml}^{-1}$ compared with $4.16 \pm$ $1.50 \mathrm{ng} \mathrm{ml} \mathrm{ml}^{-1}$ for Group 3: $P<0.05$ ) and (b) the following recrudescence phase (beginning of the second cycle) at the spring equinox (on day 405 the testosterone concentration was $4.03 \pm 0.97 \mathrm{ng} \mathrm{ml}^{-1}$ for Group 1 compared with $16.59 \pm 6.15 \mathrm{ng} \mathrm{ml}^{-1}$ for Group 3: $P<0.05$ ).

\section{Discussion}

These results show, for the first time in male hedgehogs, that reproductive activity (testicular volume, plasma testosterone and $\mathrm{LH}$ concentrations), observed in the natural environment ( $\mathrm{El}$ Omari et al., 1989), can be entrained by an artificial light regimen. The results also demonstrate that the artificial light regimen induced significant and reproducible changes in gonadal activity. In our experiments, hedgehogs submitted to an accelerated artificial light regimen that mimics in six months the photoperiodic changes that normally occur in twelve months, presented two successive reproductive cycles in one year, while the controls had only one. The characteristic changes in
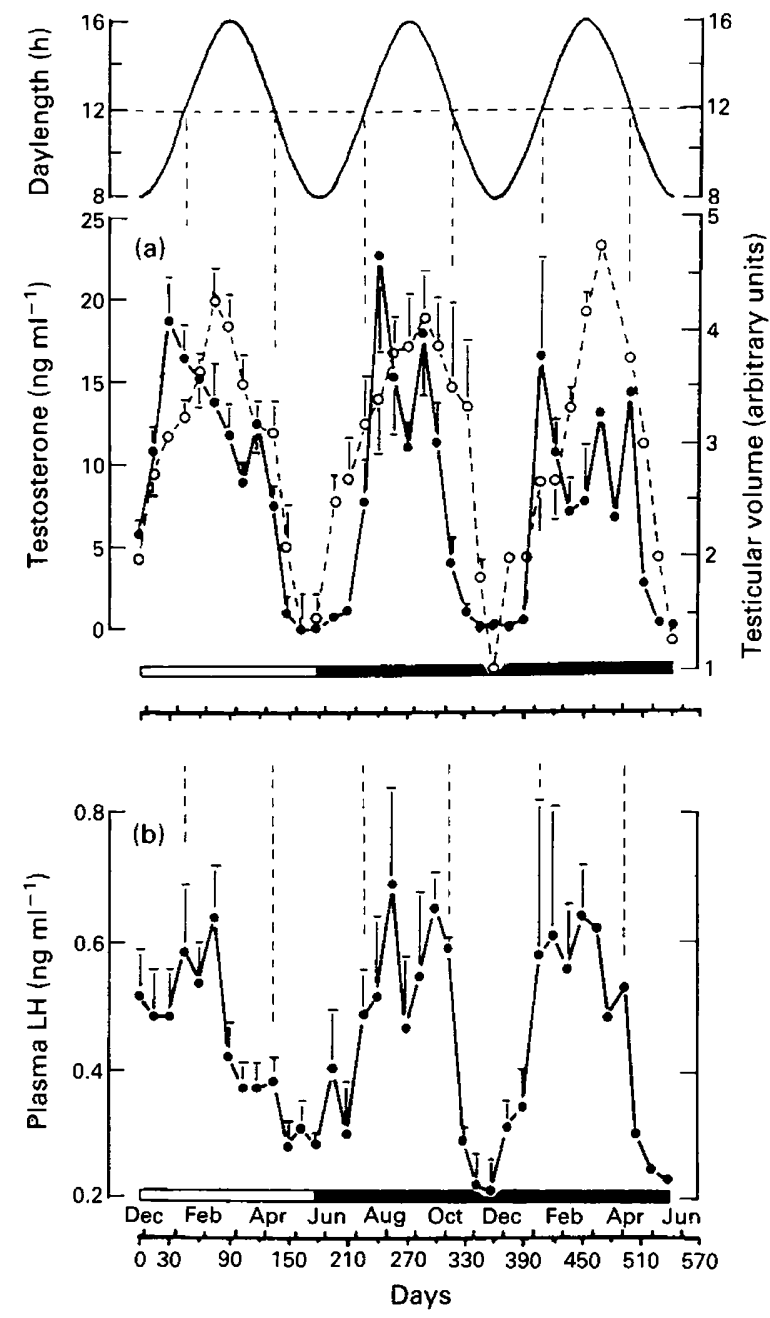

Fig. 5. Comparison of (a) testicular volume (c) and plasma testosterone concentrations $(\bullet)$ and (b) LH concentrations in male hedgehogs $(n=7)$ submitted to a 6-month artificial light regimen (top of figure) and to two successive ambient temperatures (first semestrial cycle ( $\square$ ) ambient temperature $=20 \pm 2^{\circ} \mathrm{C}$; second and third semestrial cycles ( ) ambient temperature $=5 \pm 1^{\circ} \mathrm{C}$ ).

pituitary-gonadal activity that occurred annually were also observed under these accelerated light regimens and followed exactly the variations in daylength (i.e. maximum endocrine activity during long days (light $>12 \mathrm{~h}$ ) and minimum activity during short days (light $<12 \mathrm{~h}$ )). Two reproductive cycles a year have previously been observed in males and females of many domestic and wild mammals when submitted to similar semestrial photoperiodic rhythms (Rougeot, 1969; Lindsay et al., 1984; Pelletier et al., 1986; Pohl, 1987).

Acceleration of the photoperiodic cycle resulted from either the winter solstice, with increasing daylengths (Group 1), or the summer solstice, with decreasing daylengths (Group 2). The animals responded to daylength and pituitary-gonadal activity was adjusted accordingly. During the first artificial cycle (Group I), the fact that the maximum activity period was longer than in the second and third cycles may be related to acclimatization to phototreatment as reproductive activity was already raised at the beginning of the experiment. In Group 2, however, the 


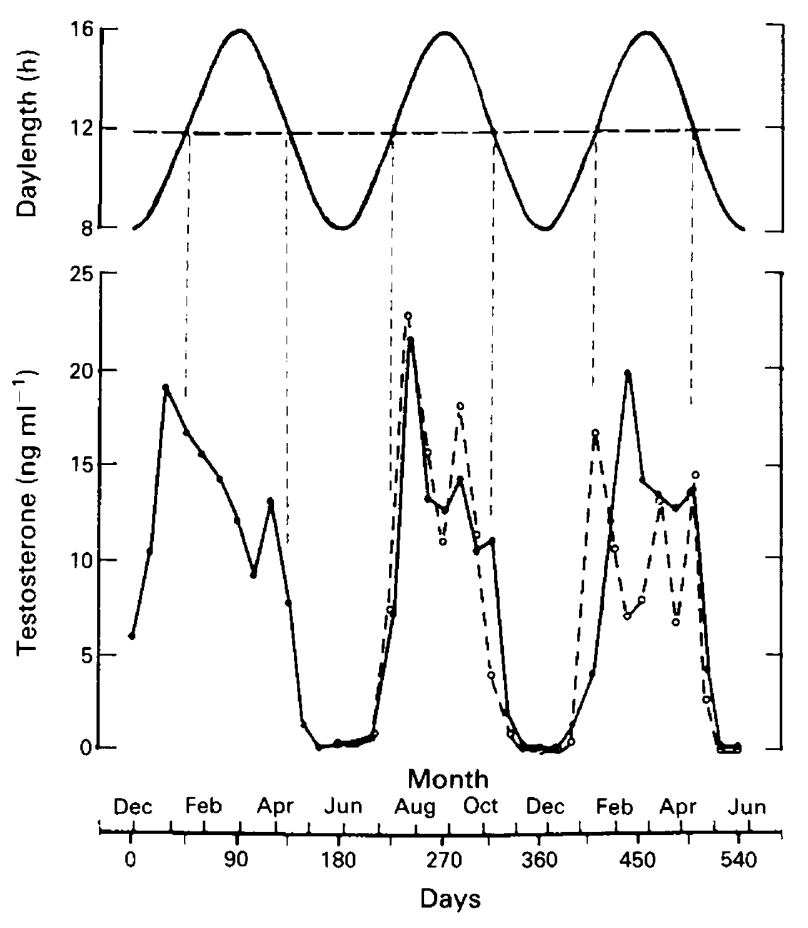

Fig. 6. Comparison of profiles of mean concentrations of plasma testosterone from male hedgehogs submitted to the same 6-month artificial light regimen (top of figure) at two different ambient temperatures $\left(\longrightarrow\right.$ Group 1: $20 \pm 2^{\circ} \mathrm{C} ;(--\mathrm{O}--)$ Group 3:5 $\pm 1^{\circ} \mathrm{C}$

acceleration of the decrease of daylength entrained a rapid involution of reproductive activity. In Groups 1 and 2, animals were submitted to reversed 6-month light cycles, under the same environmental parameters (food ad libitum, temperature $20 \pm 2^{\circ} \mathrm{C}$ ), and the reproductive changes were driven in exact opposition. These results demonstrate the strength of photoperiod as an entraining agent of the reproductive activity in hedgehogs, and is in agreement with work on animals subjected to transequatorial displacement (Marshall, 1937; Thwaites, 1965) or submitted to reversed annual photoperiodic schedules (Wodzicka-Tomaszewska et al,, 1967; Pelletier and Ortavant, 1970; Travis and Pilbeam, 1980; Karsch et al., 1984).

Exposure to a cold environment $\left(5^{\circ} \mathrm{C}\right.$ ) (Group 3) did not prevent the entrainment of testicular volume and hormone changes by the semestrial artificial light cycle, and the pattern of the reproductive cycle was almost similar, in amplitude and in phase, to Group $1\left(20^{\circ} \mathrm{C}\right)$. These results demonstrate, in hedgehogs, hibernating mammals, that the influence of low temperature, generally considered of prime importance, is subordinate to that of the photoperiod, as is the case in non-hibernating mammals (Wodzicka-Tomaszewska et al., 1967). Nevertheless, in Group 3, the small advance of the regression, at the artificial autumn equinox, may be related to a sensitivity to low temperatures as already observed in hedgehogs in summer (Saboureau, 1981). In golden hamsters, it has also been shown that the testicular involution induced by short photoperiods was accelerated by low temperatures (Pevet et al., 1986). The similar shift observed during the following recrudescence, before the artificial spring equinox, is more difficult to explain, unless gonadal reactivation is spontaneous and occurs, as observed in all other experiments under semestrial light regimen, nearly two months after the beginning of the resting phase. The increase in $\mathrm{LH}$ concentrations in animals kept at $5^{\circ} \mathrm{C}$ during the second part of the activity period cannot be explained at the moment, but it may be due either to a stimulatory effect of the low temperature on pituitary hormone secretion or the consequence of a lower metabolic turnover of $\mathrm{LH}$.

In hedgehogs the reproductive cycle seems to be endogenous (Saboureau, 1981) and is adjusted to natural conditions over the period of one year by external factors, as in many other mammals, in which endogenous reproductive rhythms are reported (sheep: Howles et al., 1982; Karsch et al., 1989; Malpaux et al., 1989; ground-squirrel: Licht et al., 1982; ferret: Boissin-Agasse et al., 1985; Boissin and Canguilhem, 1988; mink: Martinet et al., 1992). The present results show that the photoperiod can be considered, among the external factors, as an important environmental 'Zeitgeber' for entrainment of seasonal reproductive function in hedgehogs.

The mechanisms by which light regulates the pituitarygonadal cycle in hedgehogs, under natural or experimental conditions, can now be specified. Nevertheless, previous results have shown that reproductive activity increases before day length increased, or was long enough (between 8 and $12 \mathrm{~h}$ ) to be stimulatory, either under natural conditions (Saboureau and Boissin, 1978; Saboureau and Dutourné, 1981) or in very severe experimental conditions (such as fasting at low temperatures, and short photoperiod: Saboureau et al, 1984; Saboureau, 1986; El Omari et al., 1987). However, the involution of the testes always occurred rapidly in hedgehogs blinded or submitted to short daylengths (light $<12 \mathrm{~h}$ ) after the summer solstice (Saboureau, 1981, 1986). Under the 6-month light regimen, these findings are confirmed by the changes in gonadotrophic and testicular activities, particularly by the regularity of the decrease of reproductive activity at the artificial autumn equinox ( $12 \mathrm{~h}$ light: $12 \mathrm{~h}$ dark). Consequently, it appears that reproduction in hedgehogs, as in some rodents (Reiter, 1973, 1974; Hoffmann, 1979; Johnston and Zucker, 1980; Boyd. 1986), is actively photoregulated, and is inhibited by the decreasing photoperiods occurring before or near the autumn equinox. As the photoperiodic time measurement is based on the existence of a circadian rhythm of photosensitivity (Elliott, 1976), it may be postulated that such a period of sensitivity to decreasing daylengths, limited to summer and early autumn, occurs in hedgehogs. In autumn and winter, the regular, spontaneous recrudescence of pituitary-testicular activity, occurring after several months of rest, may correspond to the development of refractoriness to short days at the central level. This hypothesis is in accordance with similar results obtained in hamsters (Turek et al., 1975; Turek and Campbell, 1979; Reiter, 1980; Hoffmann, 1981).

Thus, in hedgehogs, as in many other photoperiodic species, the pineal gland and its hormonal secretions seem to be involved in the photoperiodic regulation of the gonadal cycle (Elliott, 1976; Reiter, 1980, 1983; Arendt et al., 1981; Hoffmann, 1981, 1985; Vivien-Roels and Pevet, 1983). This contention is supported by studies that showed that ultrastructural changes occurred in pinealocytes during the sexual cycle (Pevet and Saboureau, 1973), that exogenous melatonin induced gonadal regression in the summer (Saboureau, 1973), and an advance in the timing of the testicular reactivation in winter (Fowler and Downloaded from Bioscientifica.com at 04/26/2023 11:24:04AM 
Racey, 1990). Saboureau et al. (1991) have also shown that photoperiodic changes are communicated via projections of the superior cervical ganglia to the pineal gland and are rapidly converted into endocrine messages.

In conclusion, in hedgehogs, photoperiod is of prime importance in the control of reproduction and it entrains and synchronizes the endogenous rhythm of reproduction. As in many other photoperiodic species, periods of photosensitivity during the year may be involved, and the pineal gland is implicated in these regulations. Further work is needed to determine how hedgehogs measure photoperiodic time over the annual cycle, and to determine, at the central level, the mechanisms and structures implied in these neuroendocrine regulations.

\section{References}

Arendt J, Symons AM and Laud C (1981) Pineal function in the sheep. Evidence for a possible mechanism mediating seasonal reproductive activity Experientia $37584-586$

Boissin J and Canguilhem B (1988) Les rythmes circannuels chez les mammifères Archives internationales de Physiologie, de Biochimie et de Biophysique 96 A289-A345

Boissin-Agasse L, Richard P and Boissin J (1985) Activité testiculaire du furet maintenu pendant plus de 4 ans en lumière permanente et température constante Comptes rendus de l'Académie des Sciences, Paris 300 685-690

Boyd IL (1986) Photoperiodic regulation of seasonal testicular regression in the wild European rabbit (Oryctolagus cuniculus) Journal of Reproduction and Fertility $77463-470$

Elliott JA (1976) Circadian rhythms and photoperiodic time measurement in mammals Federation Proceedings 35 2339-2.341

El Omari B, Cherel Y, Le Maho $Y$ and Saboureau M (1987) Jeûne total et exposition au froid chez le Hérisson en période d'hibernation Bulletin de la Société d'Ecophysiologie 12 147-159

El Omari B, Lacroix A and Saboureau M (1989) Daily and seasonal variations in plasma $\mathrm{LH}$ and testosterone concentrations in the adult male hedgehog (Erinaceus europaeus) Jourmal of Reproduction and Fertility 86 145-155

Fowler PA (1988) Seasonal endocrine cycles in the European hedgehog, Erinaceus europaeus journal of Reproduction and Fertility 84 259-272

Fowler PA and Racey PA (1990) Effect of melatonin administration and long day-length on endocrine cycle in the hedgehog Erinaceus europaeus Joumal of Pineal Research 8 193-204

Hoffmann K (1979) Photoperiod, pineal, melatonin and reproduction in hamsters. In The Pineal Gland of Vertebrates including Man pp 397-415 Eds J Ariëns-Kappers and P Pevet. Elsevier/North-Holland Biomedical Press, Amsterdam

Hoffmann K (1981) Photoperiodic function of the mammalian pineal organ. In The Pineal Organ: Photobiology, Biochemistry, Endocrinology pp 123-138 Eds A Oksche and P Pevet. Elsevier Science Publishers (Biomedical Division), Amsterdam

Hoffmann K (1985) Interaction between photoperiod, pineal and seasonal adaptation in mammals. In The Pineal Gland: Current State of Pineal Research pp 211-227 Eds B Mess, C Ruzsas, L Tima and P Pevet. Akademia Kiado, Budapest/Elsevier Science Publishers, Amsterdam

Howles CM, Craigon J and Hayes NB (1982) Long-term rhythms of testicular volume and plasma prolactin concentrations in rams reared for 3 years in constant photoperiod Joumal of Reproduction and Fertility 65 439-446

Johnston PG and Zucker I (1980) Photoperiodic regulation of the testes of adult white-footed mice (Peromyscus leucopus) Biology of Reproduction 23 859-866

Karsch FJ, Bittman EL, Foster DL, Goodman RL, Legan SJ and Robinson JE (1984) Neuroendocrine basis of seasonal reproduction Recent Progress in Hormone Research 40 185-232

Karsch FJ, Robinson JE, Woodfill CJI and Brown MB (1989) Circannual cycles of luteinizing hormone and prolactin secretion in ewes during prolonged exposure to a fixed photoperiod: evidence for an endogenous reproductive rhythm Biology of Reproduction 41 1034-1046

Licht P, Zucker I, Hubbard G and Boshes M (1982) Circannual rhythms of plasma testosterone and luteinizing hormone levels in golden-mantled ground squirrels (Spermophilus lateralis) Biology of Reproduction 27 411-418
Lincoln GA (1978) The photoperiodic control of seasonal breeding in rams. In Comparative Endocrinology pp 149-152 Eds PJ Gaillard and HH Boer. Elsevier/North-Holland Biomedical Press, Amsterdam

Lincoln GA and Peet MJ (1977) Photoperiodic control of gonadotrophin secretion in the ram: a detailed study of the temporal changes in plasma levels of follicle-stimulating hormone, luteinizing hormone and testosterone following an abrupt switch from long to short days Joumal of Endocrinology $\mathbf{7 4}$ 355-367

Lincoln GA and Short RV (1980) Seasonal breeding: Nature's contraceptive Recent Progress in Hormone Research 36 1-52

Lindsay DR, Pelletier J, Pisselet C and Courot M (1984) Changes in photoperiod and nutrition and their effect on testicular growth of rams Journal of Reproduction and Fertility 71 351-356

Malpaux B, Robinson JE, Wayne NL and Karsch FJ (1989) Regulation of the onset of the breeding season of the ewe: importance of long days and of an endogenous reproductive rhythm Joumal of Endocrinology 122 269-278

Marshall FHA (1937) On the change over in the oestrus cycle in animals after transference across the Equator, with further observations on the incidence of the breeding seasons and the factor controlling periodicity Proceedings of the Royal Society, London Series B 122 413-428

Martinet L, Mondain-Monval M and Monnerie R (1992) Endogenous circannual rhythms and photorefractoriness of testis activity, moult and prolactin concentrations in mink (Mustela vison) Journal of Reproduction and Fertility 95 $325-338$

Ortavant R, Pelletier J, Ravault JP, Thimonier J and Volland-Nail P (1985) Photoperiod: main proximal and distal factor of the circannual cycle of reproduction in farm mammals Oxford Reviews of Reproductive Biology 7 305-345

Pelletier J and Ortavant R (1970) Influence du photopériodisme sur les activités sexuelle, hypophysaire et hypothalamique du bélier Ile-de-France. In $L a$ photorégulation de la reproduction chez les Oiseaux et les Mammiferes pp 483-495 Eds J Benoit and I Assenmacher. Editions du C.N.R.S., Paris

Pelletier J and Thimonier J (1987) The measurment of daylength in the Ile-de-France ram Journal of Reproduction and Fertility 81 181-186

Pelletier J, Ravault JP, Thimonier J, Volland-Nail P and Ortavant R (1986) Annual cycle of gonadotropic activity and photostimulation in the ram. In Endocrine Regulations as Adaptive Mechanisms to the Environment pp 143-154 Eds I Assenmacher and J Boissin. Editions du C.N.R.S., Paris

Pévet $\mathbf{P}$ and Saboureau M (1973) L'épiphyse du Hérisson (Erinaceus europaeus L.) mâle. I-Les pinéalocytes et les variations ultrastructurales considérées au cours du cycle sexuel Zeitschrift fur Zellforschung 143 367-385

Pévet P, Vivien-Roels B and Bonn D (1986) Effect of temperature on the gonadal atrophy induced by short photoperiod in the golden hamster. In Endocrine Regulations as Adaptive Mechanisms to the Environment pp 201-206 Eds I Assenmacher and I Boissin. Editions du C.N.R.S., Paris

Pohl H (1987) Control of annual rhythms of reproduction and hibernation by photoperiod and temperature in the Turkish hamster Journal of Thermal Biology 12 119-123

Reiter RJ (1973) Pineal control of a seasonal reproductive rhythm in male golden hamsters exposed to natural daylight and temperature Endocrinology $92423-430$

Reiter RJ (1974) Circannual reproductive rhythms in mammals related to photoperiod and pineal function: a review Chronobiologia 1 365-395

Reiter RJ (1980) The pineal and its hormones in the control of reproduction in mammals Endocrine Reviews 1 109-131

Reiter RJ (1983) Adaptations of the reproductive system of rodents to changing photoperiodic conditions. In Adaptations to Terrestrial Environments pp 193201 Eds NS Margaris, M Arianoustou-Faraggitaki and RJ Reiter. Plenum Publishing Corporation, New York

Rougeot J (1969) Accélération du rythme de la reproduction chez le mouflon de Corse (Ovis ammon musimon Schreber, 1782) au moyen de cycles photopériodiques semestriels Annales de Biologie Animale, Biochimie, Biophysique 9 441-443

Saboureau M (1973) Effets de la sérotonine et de la mélatonine sur l'appareil génital du Hérisson mâle (Erinaceus europaeus L.) au cours de la période d'activité sexuelle Comptes Rendus de la Société de Biologie 167 712-717

Saboureau M (1981) Environmental factors and regulation of the annual testicular cycle in a hibernating mammal: the hedgehog. In Photoperiodism and Reproduction in Vertebrates pp 319-337 Eds R Ortavant, J Pelletier and JP Ravault. Les Colloques de l'I.N.R.A.

Saboureau M (1986) Hibernation in the hedgehog: influence of external and internal factors. In Living in the Cold - Physiological and Biochemical Adaptations Downloaded from Bioscientifica.com at 04/26/2023 11:24:04AM 
pp 253-263 Eds HC Heller, XJ Musacchia and LCH Wang. Elsevier, New York

Saboureau M and Boissin J (1978) Variations saisonnières de la testostéronémie et de la thyroxinémie chez le Hérisson (Erinaceus europaeus L.) Comptes Rendus de l'Académie des Sciences, Paris 286 1479-1482

Saboureau M and Boissin J (1983) Endocrine cycles and hibernation in the hedgehog: mechanisms of adaptation to natural variations in the environment. In Adaptations to Terrestrial Environments pp 203-217 Eds NS Margaris, $\mathrm{M}$ Arianoutsou-Farraggitaki and RJ Reiter. Plenum Publishing Corporation, New York

Saboureau M and Dutourné B (1981) The reproductive cycle in the male hedgehog (Erinaceus europaeus L.): a study of endocrine and exocrine testicular functions Reproduction, Nutrition, Développement 21 109-126

Saboureau M, Laurent G and Boissin J (1979) Daily and seasonal rhythms of locomotor activity and adrenal function in male hedgehogs (Erinaceus europaeus L.) Journal of Interdisciplinary Cycle Research 10 249-266

Saboureau M, Castaing L and Boissin J (1984) Influence du taux plasmatique de testostérone et du jeûne sur les variations automnales et hivernales de l'activité motrice du Hérisson, Erinaceus europaeus L. Comptes Rendus de l'Académie des Sciences, Paris 299 239-244
Saboureau M, Vivien-Roels B and Pévet, P (1991) Pineal melatonin concentrations during day and night in the adult hedgehog: effect of a light pulse at night and superior cervical ganglionectomy Journal of Pineal Research 11 $92-98$

Thwaites CJ (1965) Photoperiodic control of breeding activity in the southdown ewe with particular reference to the effects of an equatorial light regime Joumal of Agricultural Science 65 57-64

Travis HF and Pilbeam TE (1980) Use of artificial light and day length to alter the life cycles of mink Journal of Animal Science 50 1108-1112

Turek FW and Campbell CS (1979) Photoperiodic regulation of neuroendocrine gonadal activity Biology of Reproduction $2032-50$

Turek FW, Eliott J, Alvis J and Menaker M (1975) Effect of prolonged exposure to nonstimulatory photoperiods on the activity of the neuroendocrine testicular axis of golden hamsters Biology of Reproduction 13 375-481

Vivien-Roels B and Pévet $\mathbf{P}$ (1983) The pineal gland and the synchronization of reproductive cycles with variations of the environmental climatic conditions, with special reference to temperature Pineal Research Reviews 191-143

Wodzicka-Tomaszewska M, Hutchinson JCD and Bennett JW (1967) Control of the annual rhythm of breeding in ewe; effect of an equatorial daylength with reversed thermal seasons Journal of Agricultural Science 68 61-67 